\title{
American Pediatric Society Presidential Address 2006: Science on the Edge With Life in the Balance
}

\author{
DAVID K STEVENSON
}

Department of Pediatrics, Stanford University School of Medicine, Stanford, California 94305

$\mathrm{A}^{\mathrm{s}}$ the president of the American Pediatric Society (APS) in its 118 th year, ${ }^{1}$ it is at least understandable, perhaps even forgivable, if I am relatively brief, to wax historical for part of my presidential remarks. I began my academic career at Stanford University. I had a good start in a good place. Now, nearly three decades later, I am the third holder of the Harold K. Faber Professorship in Pediatrics at Stanford, after Norman Kretchmer and Philip Sunshine. Both of the previous holders of this chair were my teachers and I honor their legacy at Stanford. Norman served as APS president in 1978 to 1979 and Phil, who served as Chief of Neonatology at Stanford for almost $20 \mathrm{y}$, received the Apgar Award from the American Academy of Pediatrics (AAP) in 2001.

However, I knew little of Harold K. Faber, whom many of my older colleagues had known personally (Fig. 1A). He came to Stanford in 1915 as head of Pediatrics, a discipline that was a subdivision of the Department of Medicine. In 1927, Pediatrics became a separate department at Stanford, and he was the first chair. He was the president of this society in 1946 to 1947 and the recipient of the Howland Award in 1956. At the 75th anniversary of the APS in May of 1963, he again addressed his colleagues. He recounted the society's genesis and adjusted history slightly, to recognize an individual whom he characterized as a "forgotten pioneer" (1), Job Lewis Smith, the second president of the APS in 1889 (Fig. 1B). As the story goes, Job Lewis Smith, who was chairman of the Pediatric Section of the 9th International Medical Congress, proposed the creation of a new, independent society on September 9, 1887. A small group of his colleagues elected Smith as the temporary chairman and selected the name "American Pediatric Society" for the new organization. One individual proposed that the new society become a section of the American Medical

Received June 29, 2006; accepted July 4, 2006.

Correspondence: David K. Stevenson, M.D., Division of Neonatal and Developmental Medicine, Department of Pediatrics, Stanford University School of Medicine, 750 Welch Rd., Suite \#315, Palo Alto, CA 94306; e-mail: dstevenson@stanford.edu

Presented at the 2006 Annual Meeting of the Pediatric Academic Societies, San Francisco, CA.

${ }^{1}$ Dr. Stevenson is the 117 th president in the 118th year of the American Pediatric Society. During the 1942 to 1943 year, there was no president of the APS.

DOI: 10.1203/01.pdr.0000242308.49575.51

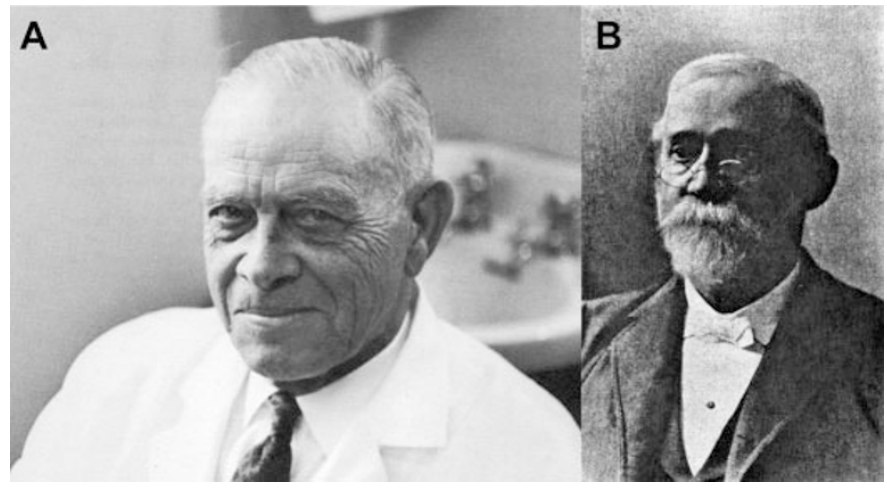

Figure 1. (A) Harold K. Faber. From Nagel GW, A Stanford Heritage. Reprinted with permission from the Stanford Alumni Medical Association. $(B)$ Job Lewis Smith. Reprinted from J Pediatr 63, Faber HK, "Job Lewis Smith, forgotten pioneer", pp 794-802, 1963, with permission from Elsevier.

Association (AMA). Fortunately, Smith insisted that a new organization "be organized on the highest possible literary and scientific basis and that it must not enter into entangling alliances." And as a result, in 1888, the APS was founded. A year later, Smith became the second president of the APS, after Abraham Jacobi, whom Smith had recommended as the first holder of the post. In Harold K. Faber's address, published in the Journal of Pediatrics in October 1963 (1), he made a strong case that, while taking nothing away from the contributions of Abraham Jacobi, "Smith was one of the two chief pioneers of American Pediatrics." Moreover, Faber left little doubt that, in his opinion, "Job Lewis Smith was the father of the APS." But, what was Faber suggesting when he pointed out Smith's admonition that the Society must not enter into "entangling alliances"? As a previous PAS program chair and now as this year's APS president, I have vigorously encouraged quite the contrary and witnessed an increasing number of partnerships and affiliations that have enriched our annual scientific meeting.

\section{PEDIATRIC ACADEMIC SOCIETIES' ALLIANCES}

Certainly, Smith must have been referring to the importance of establishing pediatrics as a specialty-separate and distinct from adult medicine. From what I know of Faber and the 
institution that was his academic home (Stanford), he could hardly have wanted to discourage the collaboration of scientists from different disciplines, not only among the life sciences, but also among the physical and chemical sciences, to address the complex problems in pediatric medicine. That is certainly Stanford's legacy and its future. In fact, as the 117th president (1), I am confident of the independence of pediatrics as a specialty; nonetheless, I am challenged to ensure that more scientific alliances, not fewer, are created, not only within the academic disciplines of pediatrics (Table 1), but across the artificial boundaries of science that, at a superficial level, have distinguished our various disciplines, as well as the adult and pediatric science communities. I am challenged to ensure the assembly of scientists, whatever their ilk, with all the variety of new tools necessary to solve the "big problems" in biology, and also the translation of our scientific breakthroughs to improve the health of children, not only in our own practices, but regionally and globally.

\section{WHAT IS PHYSIOLOGY?}

As a physician and scientist, I have always been interested in physiology, which I consider to be a basic science. This notion that the study of function in living things is a basic science is held as well by many others among you. Yet, how is it that, at Stanford, we do not even have a Department of Physiology? Instead, we describe the kind of biologic function which is our particular interest; for example, cellular and molecular. Such designations are artificial, but probably have some usefulness.

George N. Somero at Stanford's Hopkins Marine Station in Monterey, and the late Peter W. Hochachka suggest in their text, Biochemical Adaptation (2), that there are other adjectives, which inform us about several kinds of physiology that, in my opinion, have special relevance for the physician. The adjectives they use to describe these conceptual approaches to physiology include: "mechanistic," "comparative," "environmental," "ecological," "evolutionary," "adaptational," and "integrative". I would like to comment briefly about several of these "physiologies," but not all of them, as their scope goes

Table 1. Pediatric Academic Societies' alliances

Pediatric Academic Societies
American Pediatric Society
Society for Pediatric Research
Ambulatory Pediatric Association of Program Directors
American Academy of Pediatrics
Alliance Organizations
American Society of Pediatric Hematology/Oncology
American Society of Pediatric Nephrology
Asian Society for Pediatric Research
Association of Pediatric Program Directors
International Pediatric Hypertension Association
Japanese Pediatric Society
Lawson Wilkins Pediatric Endocrine Society
North American Society for Pediatric Gastroenterology, Hepatology \&
$\quad$ Nutrition
Programme for Global Paediatric Research
Reach Out and Read Program
Society for Adolescent Medicine

\section{Pediatric Academic Societies}

Ambulatory Pediatric Association of Program Directors

American Academy of Pediatrics

nce Organization

American Society of Pediatric Hematology/Oncology

American Society of Pediatric Nephrology

Research

International Pediatric Hypertension Association

Japanese Pediatric Society

Lawson Wilkins Pediatric Endocrine Society

North American Society for Pediatric Gastroenterology, Hepatology \& beyond my purpose in this talk. In particular, I will comment on mechanistic physiology, comparative physiology, and integrative physiology, without any intent to demote the other physiologies in importance or relevance to the human condition and our understanding of biochemical adaptation.

"Mechanistic physiology" is focused on discovering how living things do what they do. Since the 17th century, scientists have contributed to what has become a largely experimental tradition, underpinning and informing 20th century Western medicine. Now in the 21st century, the borrowing of concepts and tools from other fields of science continues to fuel mechanistic physiology. The new imaging technologies serve as modern examples of such synergies.

"Comparative physiology" often complements mechanistic physiology. In fact, many mechanistic physiologists are also comparative physiologists. Moreover, a variety of organisms provide unique experimental opportunities. In particular, organisms adapted to extreme environmental niches often allow fundamental principles to be deduced through comparative studies, the conservation of certain essential processes implying that discoverable structural modifications must inform such preserved function.

However, it is "integrative physiology" that seems to be most demanding for the expansion of scientific alliances. The goal of such physiology is to study function "across all levels of biologic organization, from the molecular to the ecological to the biogeographical." Indeed, after mapping the human genome, our intensive focus is now on function. As scientists, we appreciate well that knowing all the letters of the genetic code does not give us all the texts that inform biologic functionality. Thus, the emphasis is not so much on the genetic map (certainly a fundamental structure), but on gene function and control as a way to understand normal development and health as well as abnormal development and disease. The theme is clear-structure and function go hand and hand. Their relationship is not static, but dauntingly dynamic. One cannot be fully investigated without considering the other, and the context of our interrogation is relevant to our discoveries. Our biochemical structures-our enzymes and structural proteins, nucleic acids, and lipoprotein structures-are always being tested by nature, that is, by natural stressors, such as, for example, temperature. One only has to consider life near the deep sea vents or fish in the arctic, living in slush, to appreciate that structural or physico-chemical modifications must occur to preserve function and conserve physiology at such extremes. Or just consider the fetus that must transition from the womb to extrauterine life.

As a part of my general commentary on physiologic investigations and scientific alliances, a few remarks on my own career might help to personalize the perspective on science that I am sharing with you.

\section{SCIENTIFIC INVESTIGATIONS}

My first serious investigative efforts began simply enough, under the supervision of John Johnson, a generous mentor and role model, at Stanford. Although I did some research in the beginning of my career on the ontogeny of the disacchari- 
dases, as many others had done before me, under the direction of Norman Kretchmer and Philip Sunshine, I was guided by John in a direction slightly off the main gastrointestinal tract toward the liver and the study of heme oxygenase (HO), another enzyme, which for me, at that point in time, was simply the first and rate limiting step in the production of bilirubin, the bile pigment causing neonatal jaundice, one of the most common problems in pediatrics.

Heme oxygenase. Only later in my career did I begin to fully appreciate that the heme catabolic pathway (Fig. 2) is a phylogenetically ancient and highly conserved system in the biology of plants and animals with many different roles in different tissues at different points in time-an essential complex of reactions supporting life on a planet rich with iron, oxygen, and light - one of innumerable biologic fulcrums or balancing points in life's biochemistry. Indeed, $\mathrm{HO}$ is the rate limiting enzyme that degrades heme to produce equimolar quantities of carbon monoxide (CO), iron, and biliverdin, which is immediately reduced by cytosolic biliverdin reductase to form bilirubin (3). Two primary isoforms of $\mathrm{HO}$, the products of single and distinct genes, have been the most studied: the inducible (HO-1) and the constitutive (HO-2) $(4,5)$. A third isoform, HO-3, has also been identified and reported to be a processed pseudogene derived from HO-2 transcripts and appears to have little activity (6).

Interestingly, HO-1 is a heat shock protein (HSP32) or, more broadly, a stress responsive protein, which can be induced by many stressors, such as heavy metals, oxidants, UV radiation, lipopolysaccharides (LPS), and thermal stress, etc. (Fig. 3) (4,7). Besides its role in maintaining homeostasis through the regulation of cellular heme and hemoprotein levels, HO-1 also has antioxidant, anti-inflammatory, and anti-apoptotic roles, mediated mostly through the bioactive metabolites of heme degradation. In fact, it is known that biliverdin and bilirubin are strong antioxidants $(8-10)$; in higher plants, biliverdin is the precursor of phytochrome, which is involved in light-induced morphogenesis; free iron is

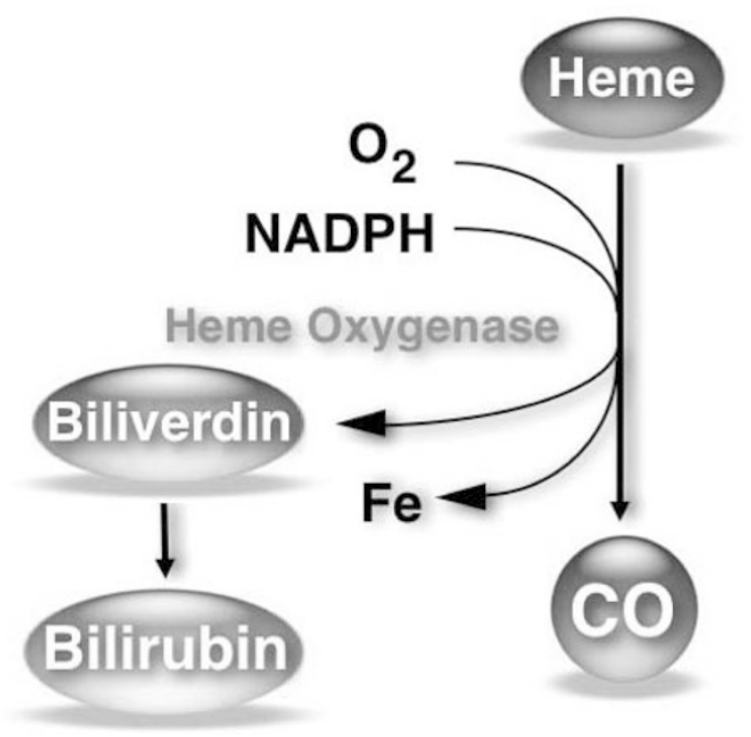

Figure 2. Heme oxygenase pathway. Carbon monoxide $(\mathrm{CO})$.

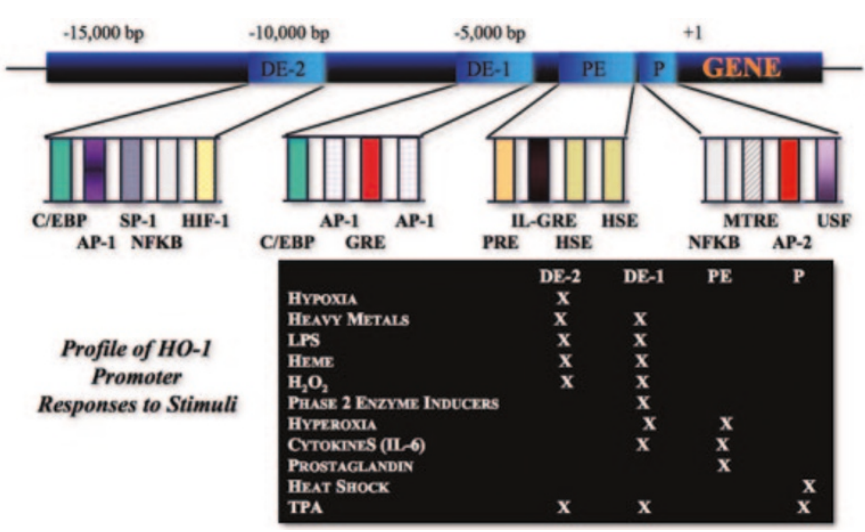

Figure 3. HO-1 promoter and its response to stimuli. Distal enhancer-2 $(D E-2)$; distal enhancer-1 (DE-1); proximal enhancer $(P E)$; and promoter $(P)$.

used for cell growth and hemoglobin formation; and $\mathrm{CO}$, a diffusible gas molecule similar to nitric oxide (NO) (11), has the ability to relax vascular smooth muscle through activation of soluble guanylyl cyclase, to serve perhaps as a signaling molecule in the CNS, and possibly to modulate the activity of other heme-containing enzymes, of which there are plenty.

Notably, there is individual variation in HO-1 gene expression in the human population, the consequences for which have not been explored fully, coming mainly from two genetic phenotypes: (1) polymorphism of (GT) dinucleotide (microsatellite) repeats found in the human HO-1 regulatory region and (2) HO-1 mutant alleles $(12,13)$. Length of these repeats is associated with variability in basal HO- 1 gene expression levels and disease states $(12,14)$. One example of a human HO-1 deficiency has been reported from Japan (15). The child suffered growth retardation, anemia, and developmental delay and eventually died. Thus, the biology related to $\mathrm{HO}$ is broad in its relevance to human well-being and ill-being is extremely complex. It is a developmentally regulated system, which is environmentally sensitive. Now older and a little wiser, with my curiosity even more piqued, I am challenged and humbled by the biology that I had embraced so naively about three decades ago. The field of HO biology has been rekindled; many secrets remain to be discovered. For me, the reaction is still fundamentally a beautiful and mysterious one, involving a variety of molecules that clearly have stood the test of time and have their unique roles to play in the lives of many different living things, including us. The physiologic process of the enzymatic degradation of heme has been conserved throughout much of nature, and I am still on a quest to understand why. And, of course, there are many "whys" that could be asked. For example, why do HO-1-deficient embryos have poorly developed placentas and rarely survive past the intrauterine stage $(16,17)$ ? Why is reduced HO-1 expression associated with pregnancy disorders, such as recurrent miscarriage, spontaneous abortions, and pre-eclampsia $(14,18)$ ? Only mechanistic and comparative physiologic experimentation is likely to provide answers to such questions.

\section{SCIENTIFIC ALLIANCES}

In the physiologic tradition, I have always been interested in studying what I have referred to as "situated biochemistry" or 
in vivo metabolism, to better understand "how things work." In collaboration with chemists, engineers, and applied physicists, I have encouraged others and helped when I could to develop some of the tools that I needed for this purpose.

Hendrik J. Vreman, my long-time research associate, "right hand" in the laboratory and friend, and Ronald J. Wong, my other "right hand" in the laboratory and also a friend, have been scientific partners in these ventures, along with many others. For example, we had to invent better breath collection systems for babies and more sensitive gas detectors. These technologies allowed us to study CO production (19), as an index of bilirubin formation (20-23), in cells (24-27), tissues $(24,28-31)$, and small and large animals (32-40), including human neonates (41-56).

With David A. Benaron, a past trainee of the National Institute of Child Health and Development (NICHD) Developmental and Neonatal Biology Training Program at Stanford, we reported the first optical time-of-flight absorbance (TOFA) imaging of biologic media in 1993 with subsequent applications to the imaging of brain function of critically ill neonates (57). Our first images were satisfying enough for our Applied Physics colleagues, as we visualized a screw inside an olive, hidden in a tube of blood (Fig. 4), but we were most excited by our images of structures inside a living mammal, using the absorption and scattering of light as our way of probing the organism (58-61). David's light-based TOFA device (Fig. 5) could be used at the bedside for assessing structure and function simultaneously, and was applied to human neonates for this purpose (60). Such technology has been developed further by David and others, and an instrument that can provide pulseless tissue oximetry is now available commercially to noninvasively detect hypoxia, ischemia, and tumors in human and animal subjects (62-64).

With David Benaron, Christopher H. and Pamela R. Contag, the latter also having been National Institutes of Healthfunded postdoctoral trainees at Stanford, and others, we were also the first to image gene expression in living mammals

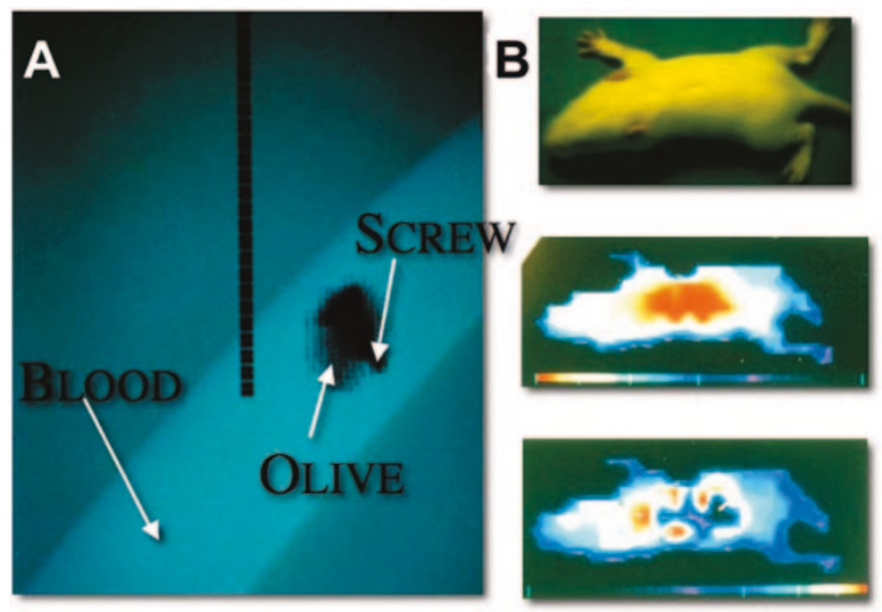

Figure 4. Optical time-of flight and absorbance imaging. (A) Visualization of a screw inside an olive, hidden in a tube of blood. $(B)$ Scan of a rat with the use of TOFA imaging. Reprinted from Science 259, Benaron DA and Stevenson DK, "Optical time-of-flight and absorbance imaging of biologic media," pp 1463-1466, 1993, with permission from Science.

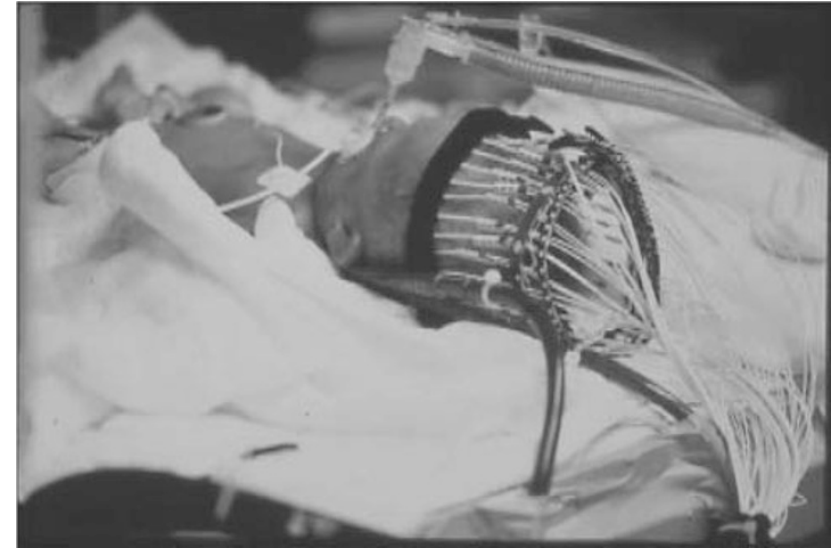

Figure 5. Optical imaging headband. Reprinted from Photochem Photobiol 68, Hintz SR et al., "Stationary headband for clinical time-of-flight optical imaging at the bedside," pp 361-369, 1998, with permission from the American Society of Photobiology.

using a luciferase (luc) reporter gene system (65), and created the HO-1-luc transgenic mouse (66), validating its use for studying the transcriptional regulation of HO-1 in development (38) and under a variety of conditions relevant to the newborn infant, such as $\mathrm{HO}$ inhibition to modulate bilirubin production $(67,68)$. These same in vivo imaging tools now have been applied to study infection (69), including hostpathogen interactions in living mammals $(70,71)$, immunomodulation (72), oncogenesis $(73,74)$, vascular and neuronal function (75), injury and repair (76), as well as stem cell trafficking and engraftment (77). But have my physiologic approaches been integrative? Should I be looking for yet other scientific alliances?

My daughter, Charlotte, has given me reason to ponder such questions. She is a marine biologist, who has been working on the eco-toxicological effects of perfluorochemicals on pglycoprotein or (p-gp), the cellular multidrug transporter, using the marine mussel, Mytilus californianus, as a model system (78). I am familiar with p-gp because of its relevance to understanding the accumulation of bilirubin in the CNS of rodents $(79,80)$. What Charlotte and her colleagues point out is that these perfluorochemicals are persistent, globally pervasive chemical pollutants that have been detected in water, wildlife, and humans. They are used in a variety of industrial household products, such as firefighting foams, textile and paper coatings, and insecticides. Their uncontrolled impact on p-gp in real life settings, including inhibition and induction, has not been considered by most of us in medicine, as we have studied only uncontaminated model systems, or worse yet we are still ignorant of such contamination, even in our models. What else of consequence could I be missing because my view has been too narrow or my scale too small?

I am now alerted by my daughter and other colleagues that I must pay attention not only to the microenvironments of the cell or of a tissue or organ of interest, but also to the macroenvironment in which we live to appreciate functionality. The earth is changing. As pediatricians, we must pay attention to the full range of potential influences that impact the systems that we study, remembering that we live in a 
world that constantly presents us with a variety of challenges, chemically and physically, even culturally and politically. The changing climate of man and our contribution to such changes cannot be ignored. Our "marginal stability" (81), the ability of our most fundamental structures to perform the functions we need in the contexts in which we reside, is at stake. And the impact of such global changes on what is more personal and intimate is likely to be profound. We need to work not only on basic problems and be narrowly focused, but also on a global scale with an expansive view. We must work together and we must embrace scientific alliances and not shun them, so that scientists from different disciplines with different tools can approach the "big problems" in biology and human health and solve them together. This is what we are doing at Stanford. This is what we all should be doing. This is not a time to ignore or dismiss science. Science should be on the edge - not the edge of funding, but the cutting edge of inquiry and the creation of new knowledge; life hangs literally in the balance.

And, as my other daughter, Terrell—a premedical student and historian studying the impact of the language, used to describe individuals with trisomy 21 , on the behavior of physicians and the public over the decades-has instructed me: "Do not get trapped by the words that set the limits of the current paradigm; see beyond your words and invent the language of your future." Science can help us see beyond our words and invent the new limits of our world.

\section{REFERENCES}

1. Faber HK 1963 Job Lewis Smith, forgotten pioneer. J Pediatr 63: 794-802

2. Hochachka PW, Somero GN 2002 Biochemical Adaptation: Mechanisms and Process in Physiological Evolution. Oxford University Press, New York, NY

3. Tenhunen R, Marver HS, Schmid R 1968 The enzymatic conversion of heme to bilirubin by microsomal heme oxygenase. Proc Natl Acad Sci USA 61:748-755

4. Maines MD 1988 Heme oxygenase: function, multiplicity, regulatory mechanisms, and clinical applications. FASEB J 2:2557-2568

5. Maines MD 1997 The heme oxygenase system: a regulator of second messenger gases. Annu Rev Pharmacol Toxicol 37:517-554

6. McCoubrey WK Jr., Huang TJ, Maines MD 1997 Isolation and characterization of a cDNA from the rat brain that encodes hemoprotein heme oxygenase-3. Eur J Biochem 247:725-732

7. Maines MD 1992 Heme Oxygenase: Clinical Applications and Functions. CRC Press, Boca Raton, FL

8. Dennery PA, McDonagh AF, Spitz DR, Rodgers PA, Stevenson DK 1995 Hyperbilirubinemia results in reduced oxidative injury in neonatal Gunn rats exposed to hyperoxia. Free Radic Biol Med 19:395-404

9. Vreman HJ, Wong RJ, Sanesi CA, Dennery PA, Stevenson DK 1998 Simultaneous production of carbon monoxide and thiobarbituric acid reactive substances in rat tissue preparations by an iron-ascorbate system. Can J Physiol Pharmacol 76:10571065

10. Dore S, Takahashi M, Ferris CD, Zakhary R, Hester LD, Guastella D, Snyder SH 1999 Bilirubin, formed by activation of heme oxygenase-2, protects neurons against oxidative stress injury. Proc Natl Acad Sci USA 96:2445-2450

11. Marks GS, Brien JF, Nakatsu K, McLaughlin BE 1991 Does carbon monoxide have a physiological function? Trends Pharmacol Sci 12:185-188

12. Yamada N, Yamaya M, Okinaga S, Nakayama K, Sekizawa K, Shibahara S, Sasaki H 2000 Microsatellite polymorphism in the heme oxygenase-1 gene promoter is associated with susceptibility to emphysema. Am J Hum Genet 66:187-195

13. Saikawa Y, Kaneda H, Yue L, Shimura S, Toma T, Kasahara Y, Yachie A, Koizumi S 2000 Structural evidence of genomic exon-deletion mediated by Alu-Alu recombination in a human case with heme oxygenase-1 deficiency. Hum Mutat 16:178179

14. Denschlag D, Marculescu R, Unfried G, Hefler LA, Exner M, Hashemi A, Riener EK, Keck C, Tempfer CB, Wagner O 2004 The size of a microsatellite polymorphism of the haem oxygenase 1 gene is associated with idiopathic recurrent miscarriage. Mol Hum Reprod 10:211-214

15. Yachie A, Niida Y, Wada T, Igarashi N, Kaneda H, Toma T, Ohta K, Kasahara Y, Koizumi S 1999 Oxidative stress causes enhanced endothelial cell injury in human heme oxygenase-1 deficiency. J Clin Invest 103:129-135

16. Poss KD, Tonegawa S 1997 Heme oxygenase-1 is required for mammalian iron reutilization. Proc Natl Acad Sci USA 94:10919-10924
17. Watanabe S, Akagi R, Mori M, Tsuchiya T, Sassa S 2004 Marked developmental changes in heme oxygenase-1 (HO-1) expression in the mouse placenta: correlation between HO-1 expression and placental development. Placenta 25:387-395

18. Bainbridge SA, Smith GN 2005 HO in pregnancy. Free Radic Biol Med 38:979-988

19. Vreman HJ, Wong RJ, Stevenson DK 2000 Carbon monoxide in breath, blood, and other tissues. In Penney DG (ed) Carbon Monoxide Toxicity. CRC Press, Boca Raton, FL, pp 19-60

20. Cohen RS, Ostrander CR, Cowan BE, Stevens GB, Hopper AO, Stevenson DK 1982 Pulmonary excretion rates of carbon monoxide using a modified technique: differences between premature and full-term infants. Biol Neonate 41:289-293

21. Stevenson DK, Bartoletti AL, Ostrander CR, Johnson JD 1980 Pulmonary excretion of carbon monoxide in the human infant as an index of bilirubin production. IV. Effects of breast-feeding and caloric intake in the first postnatal week. Pediatrics 65:1170-1172

22. Stevenson DK, Ostrander CR, Cohen RS, Johnson JD, Schwartz HC 1981 Pulmonary excretion of carbon monoxide in the human infant as an index of bilirubin production. IIb. Evidence for the possible effect of maternal prenatal glucose metabolism on postnatal bilirubin production in a mixed population of infants. Eur J Pediatr 137:255-259

23. Stevenson DK, Ostrander CR, Hopper AO, Cohen RS, Johnson JD 1981 Pulmonary excretion of carbon monoxide as an index of bilirubin production. IIa. Evidence for possible delayed clearance of bilirubin in infants of diabetic mothers. J Pediatr 98:822-824

24. Vreman HJ, Stevenson DK 1988 Heme oxygenase activity as measured by carbon monoxide production. Anal Biochem 168:31-38

25. Vreman HJ, Ekstrand BC, Stevenson DK 1993 Selection of metalloporphyrin heme oxygenase inhibitors based on potency and photoreactivity. Pediatr Res 33:195-200

26. Murphy BJ, Laderoute KR, Vreman HJ, Grant TD, Gill NS, Stevenson DK, Sutherland RM 1993 Enhancement of heme oxygenase expression and activity in A431 squamous carcinoma multicellular tumor spheroids. Cancer Res 53:2700 2703

27. Kaplan M, Vreman HJ, Hammerman C, Leiter C, Rudensky B, MacDonald MG, Stevenson DK 1998 Combination of ABO blood group incompatibility and glucose6-phosphate dehydrogenase deficiency: effect on hemolysis and neonatal hyperbilirubinemia. Acta Paediatr 87:455-457

28. Kim CB, Hintz SR, Vreman HJ, Stevenson DK.1988. In vitro carbon monoxide production by the small intestine of suckling and adult Wistar rats: effect of parenteral tin-protoporphyrin. Dev Pharmacol Ther;11:166-172

29. Vreman HJ, Lee OK, Stevenson DK 1991 In vitro and in vivo characteristics of a heme oxygenase inhibitor: ZnBG. Am J Med Sci;302:335-341

30. Vreman HJ, Wong RJ, Kim EC, Nabseth DC, Marks GS, Stevenson DK 2000 Haem oxygenase activity in human umbilical cord and rat vascular tissues. Placenta 21:337-344

31. McLaughlin BE, Lash GE, Graham CH, Smith GN, Vreman HJ, Stevenson DK, Marks GS, Nakatsu K, Brien JF 2001 Endogenous carbon monoxide formation by chorionic villi of term human placenta. Placenta 22:886-888

32. Hamori CJ, Vreman HJ, Rodgers PA, Stevenson DK 1989 Zinc protoporphyrin inhibits CO production in rats. J Pediatr Gastroenterol Nutr 8:110-115

33. Vreman HJ, Gillman MJ, Stevenson DK 1989 In vitro inhibition of adult rat intestinal heme oxygenase by metalloporphyrins. Pediatr Res 26:362-365

34. Rodgers PA, Vreman HJ, Stevenson DK 1990 Heme catabolism in rhesus neonates inhibited by zinc protoporphyrin. Dev Pharmacol Ther 14:216-222

35. Vreman HJ, Rodgers PA, Stevenson DK 1990 Zinc protoporphyrin administration for suppression of increased bilirubin production by iatrogenic hemolysis in rhesus neonates. J Pediatr 117:292-297

36. Vallier HA, Rodgers PA, Castillo RO, Stevenson DK 1991 Absorption of zinc deuteroporphyrin IX 2,4 bis glycol by the neonatal rat small intestine in vivo. Dev Pharmacol Ther 17:109-115

37. Vallier HA, Rodgers PA, Stevenson DK 1991 Oral administration of zinc deuteroporphyrin IX 2,4 bis glycol inhibits heme oxygenase in neonatal rats. Dev Pharmacol Ther 17:220-222

38. Wong RJ, Nguyen XN, Zhao H, Vreman HJ, Contag CH, Stevenson DK 2002 Developmentally regulated pattern of heme oxygenase-1 expression in the mouse brain. Pediatr Res 51:328A

39. Dercho RA, Nakatsu K, Wong RJ, Stevenson DK, Vreman HJ 2006 Determination of in vivo carbon monoxide production in laboratory animals via exhaled air. J Pharmacol Toxicol Methods doi:10.1016/j.physletb. 2003.10.071.

40. Vreman HJ, Wong RJ, Kadotani T, Stevenson DK 2005 Determination of carbon monoxide $(\mathrm{CO})$ in rodent tissue: Effect of heme administration and environmental CO exposure. Anal Biochem 341:280-289

41. Bartoletti AL, Stevenson DK, Ostrander CR, Johnson JD 1979 Pulmonary excretion of carbon monoxide in the human infant as an index of bilirubin production. I. Effects of gestational and postnatal age and some common neonatal abnormalities. J Pediatr 94:952-955

42. Uetani Y, Nakamura H, Okamoto O, Yamazaki T, Vreman HJ, Stevenson DK 1989 Carboxyhemoglobin measurements in the diagnosis of $\mathrm{ABO}$ hemolytic disease. Acta Paediatr Jpn 31:171-176

43. Stevenson DK, Vreman HJ, Oh W, Fanaroff AA, Wright LL, Lemons JA, Verter J, Shankaran S, Tyson JE, Korones SB, Bauer CR, Stoll BJ, Papile LA, Donovan EF, Okah F, Ehrenkranz RA 1994 Bilirubin production in healthy term infants as measured by carbon monoxide in breath. Clin Chem 40:1934-1939

44. Vreman HJ, Stevenson DK, Oh W, Fanaroff AA, Wright LL, Lemons JA, Wright E, Shankaran S, Tyson JE, Korones SB, Bauer CR, Stoll BJ, Papile LA, Donovan EF, Ehrenkranz RA 1994 Semiportable electrochemical instrument for determining carbon monoxide in breath. Clin Chem 40:1927-1933 
45. Balaraman V, Pelke S, DiMauro S, Cheung S, Stevenson DK, Easa D 1995 End-tidal carbon monoxide in newborn infants: observations during the 1st week of life. Biol Neonate 67:182-185

46. Vreman HJ, Baxter LM, Stone RT, Stevenson DK 1996 Evaluation of a fully automated end-tidal carbon monoxide instrument for breath analysis. Clin Chem 42:50-56

47. Stevenson DK, Vreman HJ 1997 Carbon monoxide and bilirubin production in neonates. Pediatrics 100:252-254

48. Kaplan M, Beutler E, Vreman HJ, Hammerman C, Levy-Lahad E, Renbaum P, Stevenson DK 1999 Neonatal hyperbilirubinemia in glucose-6-phosphate dehydrogenase-deficient heterozygotes. Pediatrics 104:68-74

49. Kaplan M, Vreman HJ, Hammerman C, Stevenson DK 1999 Neonatal bilirubin production, reflected by carboxyhaemoglobin concentrations, in Down's syndrome. Arch Dis Child Fetal Neonatal Ed 81:F56-F60

50. Vreman HJ, Wong RJ, Harmatz P, Fanaroff AA, Berman B, Stevenson DK 1999 Validation of the Natus CO-Stat ${ }^{\mathrm{TM}}$ End Tidal Breath Analyzer in children and adults. J Clin Monit Comput 15:421-427

51. Stevenson DK, Fanaroff AA, Maisels MJ, Young BW, Wong RJ, Vreman HJ, MacMahon JR, Yeung CY, Seidman DS, Gale R, Oh W, Bhutani VK, Johnson LH, Kaplan M, Hammerman C, Nakamura H 2001 Prediction of hyperbilirubinemia in near-term and term infants. Pediatrics 108:31-39

52. Kaplan M, Hammerman C, Vreman HJ, Stevenson DK, Beutler E 2001 Acute hemolysis and severe neonatal hyperbilirubinemia in glucose-6-phosphate dehydrogenase-deficient heterozygotes. J Pediatr 139:137-140

53. Kaplan M, Hammerman C, Rubaltelli FF, Vilei MT, Levy-Lahad E, Renbaum P, Vreman HJ, Stevenson DK, Muraca M 2002 Hemolysis and bilirubin conjugation in association with UDP-glucuronosyltransferase 1A1 promoter polymorphism. Hepatology 35:905-911

54. Kaplan M, Muraca M, Hammerman C, Rubaltelli FF, Vilei MT, Vreman HJ, Stevenson DK 2002 Imbalance between production and conjugation of bilirubin: a fundamental concept in the mechanism of neonatal jaundice. Pediatrics 110:E47E51

55. Hendler I, Baum M, Kreiser D, Schiff E, Druzin M, Stevenson DK, Seidman DS 2004 End-tidal breath carbon monoxide measurements are lower in pregnant women with uterine contractions. J Perinatol 24:275-278

56. Kreiser D, Baum M, Seidman DS, Fanaroff A, Shah D, Hendler I, Stevenson DK, Schiff E, Druzin ML 2004 End tidal carbon monoxide levels are lower in women with gestational hypertension and pre-eclampsia. J Perinatol 24:213-217

57. Benaron DA, Stevenson DK 1993 Optical time-of-flight and absorbance imaging of biologic media. Science 259:1463-1466

58. Benaron DA, Ho DC, Spilman S, Van Houten JP, Stevenson DK 1994 Tomographic time-of-flight optical imaging device. Adv Exp Med Biol 361:207-214

59. Van Houten JP, Benaron DA, Spilman S, Stevenson DK 1996 Imaging brain injury using time-resolved near infrared light scanning. Pediatr Res 39:470-476

60. Hintz SR, Benaron DA, van Houten JP, Duckworth JL, Liu FW, Spilman SD, Stevenson DK, Cheong WF 1998 Stationary headband for clinical time-of-flight optical imaging at the bedside. Photochem Photobiol 68:361-369

61. Hintz SR, Cheong WF, van Houten JP, Stevenson DK, Benaron DA 1999 Bedside imaging of intracranial hemorrhage in the neonate using light: Comparison with ultrasound, computed tomography, and magnetic resonance imaging. Pediatr Res 45:54-59

62. Benaron DA, Parachikov IH, Cheong WF, Friedland S, Rubinsky BE, Otten DM, Liu FW, Levinson CJ, Murphy AL, Price JW, Talmi Y, Weersing JP, Duckworth JL, Horchner UB, Kermit EL 2005 Design of a visible-light spectroscopy clinical tissue oximeter. J Biomed Opt 10:44005

63. Benaron DA, Parachikov IH, Friedland S, Soetikno R, Brock-Utne J, van der Starre PJ, Nezhat C, Terris MK, Maxim PG, Carson JJ, Razavi MK, Gladstone HB, Fincher
EF, Hsu CP, Clark FL, Cheong WF, Duckworth JL, Stevenson DK 2004 Continuous, noninvasive, and localized microvascular tissue oximetry using visible light spectroscopy. Anesthesiology 100:1469-1475

64. Maxim PG, Carson JJ, Benaron DA, Loo BW Jr., Xing L, Boyer AL, Friedland S 2005 Optical detection of tumors in vivo by visible light tissue oximetry. Technol Cancer Res Treat 4:227-234

65. Contag CH, Spilman SD, Contag PR, Oshiro M, Eames B, Dennery PA, Stevenson DK, Benaron DA 1997 Visualizing gene expression in living mammals using a bioluminescent reporter. Photochem Photobiol 66:523-531

66. Zhang W, Feng JQ, Harris SE, Contag PR, Stevenson DK, Contag CH 2001 Rapid in vivo functional analysis of transgenes in mice using whole body imaging of luciferase expression. Transgenic Res 10:423-434

67. DeSandre GH, Wong RJ, Morioka I, Contag CH, Stevenson DK 2006 The effectiveness of oral tin mesoporphyrin prophylaxis in reducing bilirubin production after an oral heme load in a transgenic mouse model. Biol Neonate 89:139-146

68. Morioka I, Wong RJ, Abate A, Vreman HJ, Contag CH, Stevenson DK 2006 Systemic effects of orally-administered zinc and tin (IV) metalloporphyrins on heme oxygenase expression in mice. Pediatr Res 59:667-672

69. Burns-Guydish SM, Olomu IN, Zhao H, Wong RJ, Stevenson DK, Contag CH 2005 Monitoring age-related susceptibility of young mice to oral Salmonella enterica serovar Typhimurium infection using an in vivo murine model. Pediatr Res 58:153158

70. Contag CH, Contag PR, Benaron DA, Stevenson DK 1998 Visualizing infection and gene expression in living animals. Yearbook Jpn Soc Perinatol 16:146

71. Contag CH, Contag PR, Mullins JI, Spilman SD, Stevenson DK, Benaron DA 1995 Photonic detection of bacterial pathogens in living hosts. Mol Microbiol 18:593603

72. Tanaka M, Swijnenburg RJ, Gunawan F, Cao YA, Yang Y, Caffarelli AD, de Bruin JL, Contag CH, Robbins RC 2005 In vivo visualization of cardiac allograft rejection and trafficking passenger leukocytes using bioluminescence imaging. Circulation;112:I105-I110

73. Sweeney TJ, Mailander V, Tucker AA, Olomu AB, Zhang W, Cao YA, Negrin RS, Contag CH 1999 Visualizing the kinetics of tumor-cell clearance in living animals. Proc Natl Acad Sci USA 96:12044-12049

74. Contag CH, Jenkins D, Contag PR, Negrin RS 2000 Use of reporter genes for optical measurements of neoplastic disease in vivo. Neoplasia 2:41-52

75. Benaron DA, Contag PR, Contag CH 1997 Imaging brain structure and function, infection and gene expression in the body using light. Philos Trans R Soc Lond B Biol Sci 352:755-761

76. Okada S, Ishii K, Yamane J, Iwanami A, Ikegami T, Katoh H, Iwamoto Y, Nakamura M, Miyoshi H, Okano HJ, Contag CH, Toyama Y, Okano H 2005 In vivo imaging of engrafted neural stem cells: its application in evaluating the optimal timing of transplantation for spinal cord injury. FASEB J;19:1839-1841

77. Cao YA, Wagers AJ, Beilhack A, Dusich J, Bachmann MH, Negrin RS, Weissman IL, Contag CH 2004 Shifting foci of hematopoiesis during reconstitution from single stem cells. Proc Natl Acad Sci USA 101:221-226

78. Stevenson CN, MacManus-Spencer LA, Luckenbach T, Luthy RG, Epel D 2006 Perfluorocarbon ecotoxicity: inhibition of a multi-drug transporter in the mussel Mytilus californianus. Environ Sci Technol 40:5580-5585

79. Hanko E, Tommarello S, Watchko JF, Hansen TW 2003 Administration of drugs known to inhibit P-glycoprotein increases brain bilirubin and alters the regional distribution of bilirubin in rat brain. Pediatr Res 54:441-445

80. Watchko JF, Daood MJ, Hansen TW 1998 Brain bilirubin content is increased in P-glycoprotein-deficient transgenic null mutant mice. Pediatr Res 44:763-766

81. Jaenicke R 1991 Protein stability and molecular adaptation to extreme conditions. Eur J Biochem 202:715-728 